\title{
Light gradients and optical microniches in coral tissues
}

\author{
Daniel Wangpraseurt ${ }^{1}$, Anthony W. D. Larkum ${ }^{1}$, Peter J. Ralph ${ }^{1}$ and Michael Kühl, ${ }^{1,2,3}$ * \\ ${ }^{1}$ Plant Functional Biology and Climate Change Cluster, Department of Environmental Sciences, University of Technology Sydney, Sydney, NSW, Australia \\ ${ }^{2}$ Marine Biological Section, Department of Biology, University of Copenhagen, Helsingør, Denmark \\ ${ }^{3}$ Singapore Centre on Environmental Life Sciences Engineering, School of Biological Sciences, Nanyang Technological University, Singapore, Singapore
}

\section{Edited by:}

Lasse Riemann, University of

Copenhagen, Denmark

\section{Reviewed by:}

Hans Paerl, University of North

Carolina at Chapel Hill, USA

Vanessa K. Michelou, University of Hawaii, USA

*Correspondence:

Michael Kühl, Marine Biological Section, Department of Biology, University of Copenhagen,

Strandpromenaden 5, 3000

Helsingør, Denmark.

e-mail:mkuhl@bio.ku.dk
Light quantity and quality are among the most important factors determining the physiology and stress response of zooxanthellate corals. Yet, almost nothing is known about the light field that Symbiodinium experiences within their coral host, and the basic optical properties of coral tissue are unknown. We used scalar irradiance microprobes to characterize vertical and lateral light gradients within and across tissues of several coral species. Our results revealed the presence of steep light gradients with photosynthetically available radiation decreasing by about one order of magnitude from the tissue surface to the coral skeleton. Surface scalar irradiance was consistently higher over polyp tissue than over coenosarc tissue in faviid corals. Coral bleaching increased surface scalar irradiance by $150 \%$ (between 500 and $700 \mathrm{~nm}$ ) relative to a healthy coral. Photosynthesis peaked around $300 \mu \mathrm{m}$ within the tissue, which corresponded to a zone exhibiting strongest depletion of scalar irradiance. Deeper coral tissue layers, e.g., $\sim 1000 \mu \mathrm{m}$ into aboral polyp tissues, harbor optical microniches, where only $\sim 10 \%$ of the incident irradiance remains. We conclude that the optical microenvironment of corals exhibits strong lateral and vertical gradients of scalar irradiance, which are affected by both tissue and skeleton optical properties. Our results imply that zooxanthellae populations inhabit a strongly heterogeneous light environment and highlight the presence of different optical microniches in corals; an important finding for understanding the photobiology, stress response, as well as the phenotypic and genotypic plasticity of coral symbionts.

Keywords: coral photobiology, bio-optics, microenvironment, tissue optics, zooxanthellae, microsensor, microgradients, ecophysiology

\section{INTRODUCTION}

Coral reefs are among the most productive and diverse ecosystems on Earth and their evolutionary success can be largely attributed to the successful interaction between scleractinian corals and their associated microorganisms, most importantly their microalgal photosymbionts (zooxanthellae) belonging to the dinoflagellate genus Symbiodinium. The quantity of light is a key environmental parameter regulating the nature of this photosymbiosis (Falkowski et al., 1990). Under optimal irradiance regimes, light stimulates symbiont photosynthesis, which provides organic carbon for the coral animal that in turn provides metabolic waste products supporting zooxanthellae photosynthesis (Muscatine et al., 1981). Excess quantities of light, however, readily lead to photoinhibition and can damage the photosynthetic apparatus. Light in combination with elevated temperature can lead to the expulsion of the zooxanthellae (and/or pigment degradation) and the breakdown of the symbiosis (Lesser, 1996; Jones et al., 1998; Warner et al., 1999). This breakdown, termed coral bleaching, has been intensively studied over the last decades, including a primary focus on the photobiology of zooxanthellae (Glynn, 1996; Brown, 1997; Hoegh-Guldberg, 1999). Despite such efforts, it is surprising that virtually nothing is known about the actual light regime surrounding the zooxanthellae in hospite, i.e., within the coral tissue, albeit the light microenvironment is a central control factor of the photoand stress physiology of zooxanthellae and their coral hosts.
The optical environment within the host tissue is likely to vary substantially in relation to the ambient macro-environment. First, direct micro-scale measurements of photon scalar irradiance (i.e., the integral quantum flux incident from all directions about a given point) on the coral tissue surface revealed scalar irradiance values reaching up to $200 \%$ of the incident downwelling photon irradiance (Kühl et al., 1995). Such enhancement is currently thought to mainly result from multiple scattering of photons in the coral skeleton below the tissue (Enriquez et al., 2005). The aragonite skeleton scatters light isotropically so that photons interacting with the skeleton are diffusely backscattered into the tissue (Enriquez et al., 2005). Diffuse scattering increases the path length of photons per vertical distance traversed, i.e., it enhances the average residence time of photons at a given depth horizon and can thereby lead to local enhancement of scalar irradiance (Kühl and Jørgensen, 1994; Enriquez et al., 2005). It is currently assumed that the light field within the coral tissue is diffuse and uniformly enhanced over the incident irradiance (Enriquez et al., 2005; Teran et al., 2010). However, the optical environment within the coral may be more complex as tissue-light interactions and the optical properties of coral tissue remain largely unexplored.

Photons interacting with tissue can have three different fates: (i) simple unimpeded transmission; (ii) absorption followed by either red-shifted re-emission (as fluorescence or phosphorescence), heat dissipation or dissipation via photochemical reactions 


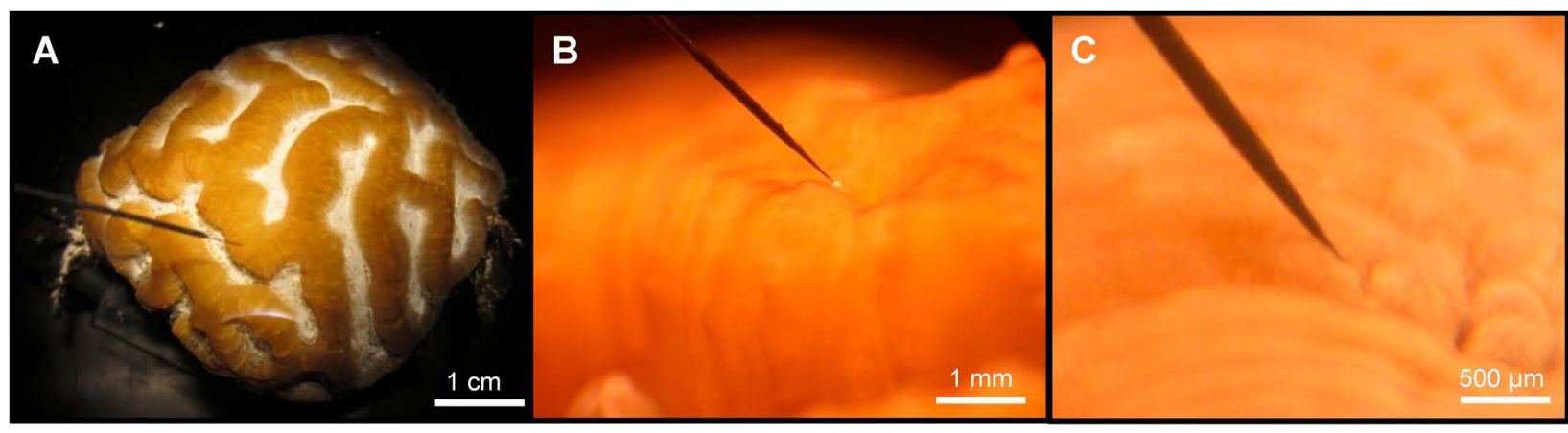

FIGURE 1 | Micro-scale scalar irradiance measurements on corals.

(A) Overview showing a small fragment of Platygyra lamellina with the scalar irradiance microprobe positioned at the coral tissue surface at a $45^{\circ}$ angle,
(B) the spherical microsensor tip (white bulb; $100 \mu \mathrm{m}$ ) at the surface of coenosarc tissue, and $\mathbf{( C )}$ the microprobe inserted into coral tissue. such as photosynthesis or radical formation; (iii) scattering and diffraction leading to a redirection of photons out of their original path. The occurrence of these events is determined by a complex interplay between the nature and direction of incident light and the optical properties of the given tissue (Wilson and Jacques, 1990). The optical properties of living tissue are best studied for human skin, but also well-described for terrestrial plants (Anderson and Parrish, 1981; Vogelmann, 1993) as well as aquatic sediments and biofilms (Kühl and Jørgensen, 1994). The development and use of fiber-optic microprobes (Vogelmann et al., 1991; Kühl, 2005) has facilitated experimental investigation of light microenvironments and optical properties within such systems (Vogelmann and Björn, 1984; Vogelmann, 1993; Vogelmann et al., 1996). Besides a few preliminary measurements (Kühl et al., 1995; Kaniewska et al., 2011), comparable studies on coral tissue are lacking. Kaniewska et al. (2011) mainly focused on comparing larger scale heterogeneity of light fields in different corals and presented only few spot measurements of scalar irradiance at a fixed depth in the coral tissue and no detailed vertical or lateral profiling was done. The presence and nature of micro-scale heterogeneity in coral light fields, both laterally over different coral tissue types and vertically within a given tissue type, have thus not been resolved.

Here we used scalar irradiance microprobes (Vogelmann and Björn, 1984; Lassen et al., 1992) to characterize the spectral light field and light penetration in coral tissues. The specific aims were (1) to directly measure light penetration in tissue of corals belonging to the family Faviidae, (2) investigate the effect of tissue type (coenosarc and polyp tissue) and loss of pigmentation (bleaching) on light microenvironments for a variety of abundant coral species, and (3) investigate how gradients of light and photosynthesis within coral tissue align with each other. Our results provide the first insight into the basic optical properties of coral tissue and describe the in hospite optical microenvironment of corals from a zooxanthellar perspective.

\section{RESULTS}

\section{LIGHT FIELDS SURROUNDING CORAL TISSUE}

Spectral scalar irradiance at the coral tissue surface (Figure 1) differed markedly between tissue types (i.e., coenosarc and polyp) both within a coral species and between species, despite identical regimes of incident collimated irradiance (Figure 2). Generally, there was an enhancement in scalar irradiance over incident irradiance reaching maximum values of $\sim 180 \%$ for photosynthetically active radiation (PAR, $400-700 \mathrm{~nm}$ ) and $\sim 250 \%$ for near-infrared radiation (NIR, 700-800 $\mathrm{nm}$ ). Scalar irradiance levels in faviid corals were systematically higher over polyp tissue than over coenosarc tissue for both PAR and NIR (Figures 2 and 3A,B). For example, the scalar irradiance measured over polyp tissue of Favites abdita, was about 1.4 and 1.3 times higher than over coenosarc tissue for PAR and NIR, respectively (Figures 3A,B). In contrast, no differences between polyp and coenosarc tissue were present in Pocillopora damicornis (Figures 3A,B). Characteristic absorption peaks of Chl $a(430-440,675 \mathrm{~nm}), \mathrm{Chl} c(460 \mathrm{~nm})$, and the carotenoid peridinin $(480-490 \mathrm{~nm})$ were found at the surface of faviid corals; these peaks were especially pronounced over polyp

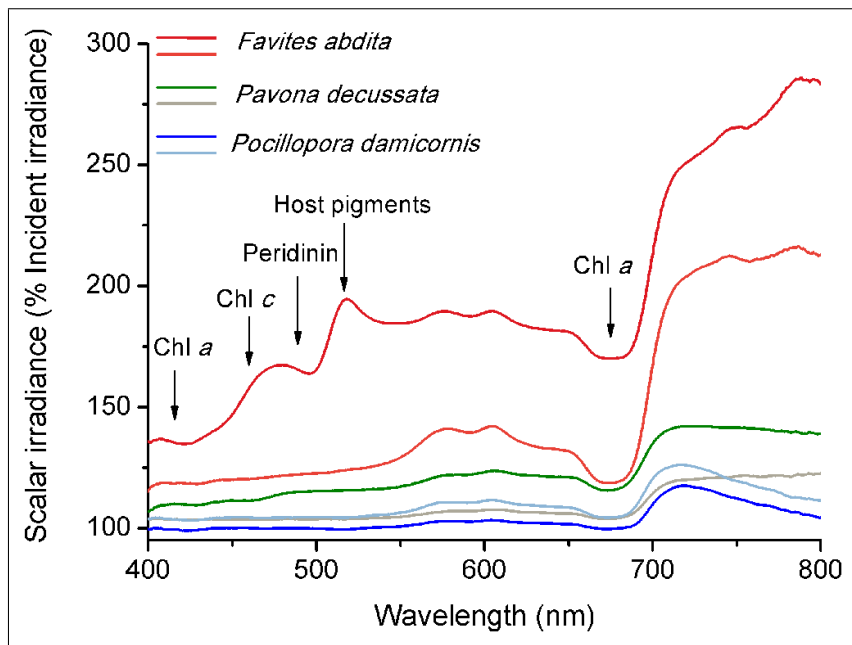

FIGURE 2 | Micro-scale spectral scalar irradiance at the tissue surface of different corals. Data were normalized to the incident downwelling spectral irradiance, $E_{d}$. Note that scale begins at $100 \% E_{d}$. Dark and light color tones represent measurements made on polyp and coenosarc tissue, respectively. Arrows show major absorption wavelengths of peridinin $(480-490 \mathrm{~nm})$, chlorophyll $c(460 \mathrm{~nm})$ and chlorophyll a (435-440, $675 \mathrm{~nm})$, and emission/reflectance of host pigments (480-590 nm). 

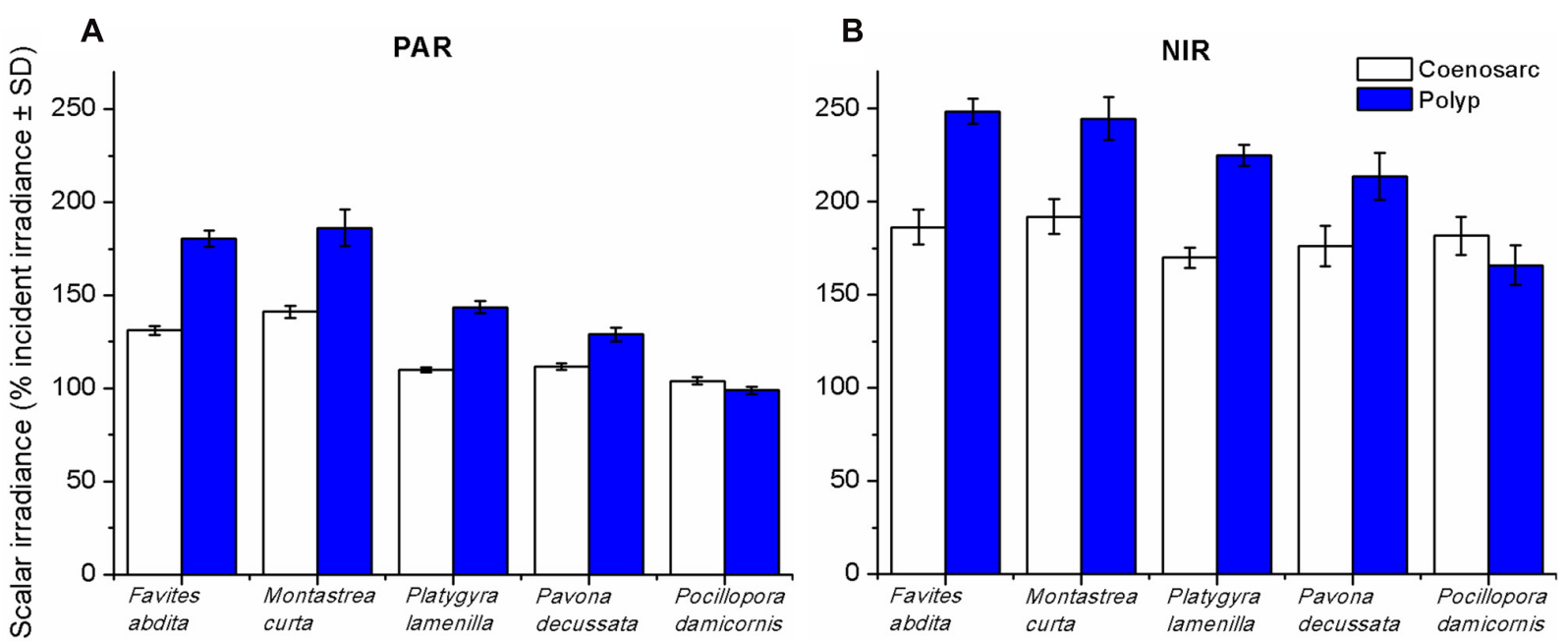

FIGURE 3 Integrated scalar irradiance (in \% of downwelling irradiance) at the tissue surface of corals. (A) PAR (photosynthetically available radiation, $400-700 \mathrm{~nm}$ ) and (B) NIR (near-infrared radiation, $700-800 \mathrm{~nm}$ ).
Data are means $\pm \mathrm{SD}(n=9)$. Measurements were done at the surface of the coenosarc (white bars) and polyp (blue bars) tissue, respectively. tissue. In comparison, spectra of Pavona decussata and Pocillopora damicornis showed less distinct spectral signatures (Figure 2). More detailed horizontal mapping of scalar irradiance across the tissue surface (from polyp mouth over walls to coenosarc) revealed strong small-scale heterogeneity (Figure 4), but consistent results were obtained between the two different tissue types (coenosarc and polyp mouth tissue). Pigmentation across the polyp walls appeared heterogeneous (patchy distribution of host pigments) as were the measurements of scalar irradiance. When the sensor was placed within a tissue fold (i.e., sphere entirely covered by tissue), irradiance was significantly attenuated (Figure 4).

\section{EFFECTS OF CORAL BLEACHING ON TISSUE SURFACE SPECTRAL SCALAR IRRADIANCE}

Loss of pigmentation (bleaching) led to a further increase in the tissue surface scalar irradiance of corals reaching $\sim 150 \%$ of the scalar irradiance levels of a healthy coral at wavelengths between $\sim 500$ and $700 \mathrm{~nm}$ (Figure 5). However, in the blue region of visible light ( $400-500 \mathrm{~nm})$ and in the NIR, bleaching only led to a slight (10-20\%) increase in scalar irradiance. Bleaching affected the light field of coenosarc tissue to a greater extent than that of polyp tissue with greatest deviations of $>10 \%$ occurring between 470-510 and 720-800 $\mathrm{nm}$.

\section{SPECTRAL SCALAR IRRADIANCE WITHIN CORAL TISSUE}

Our microprofiles revealed the presence of strong light gradients within coral tissue (Figures 6A,B). Over the visible range (PAR, 400-700 nm), scalar irradiance was attenuated toward the skeleton. For coenosarc tissue, scalar irradiance of PAR decreased from $\sim 132$ to $74 \%$ of the incident downwelling irradiance over a distance of $400 \mu \mathrm{m}$. Such decrease in PAR was even more pronounced for a $1100-\mu \mathrm{m}$ thick polyp tissue, where PAR

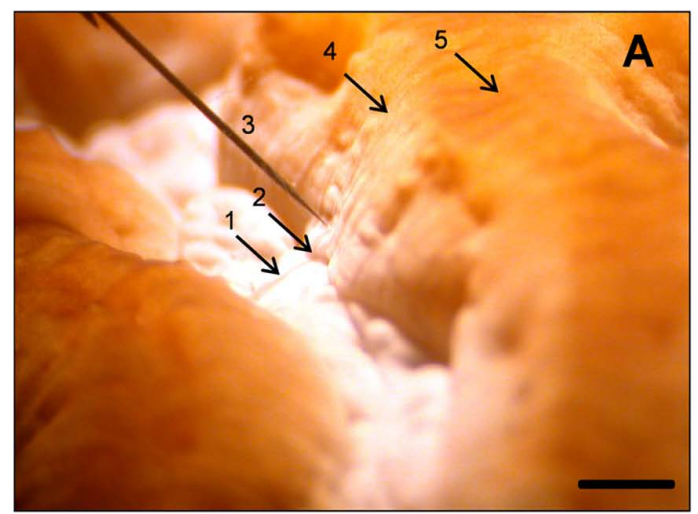

FIGURE 4 | Mapping of spectral scalar irradiance heterogeneity along one coral polyp in Platygyra lamellina. (A) Photograph detailing the five different measurement positions along a horizontal tissue surface gradient

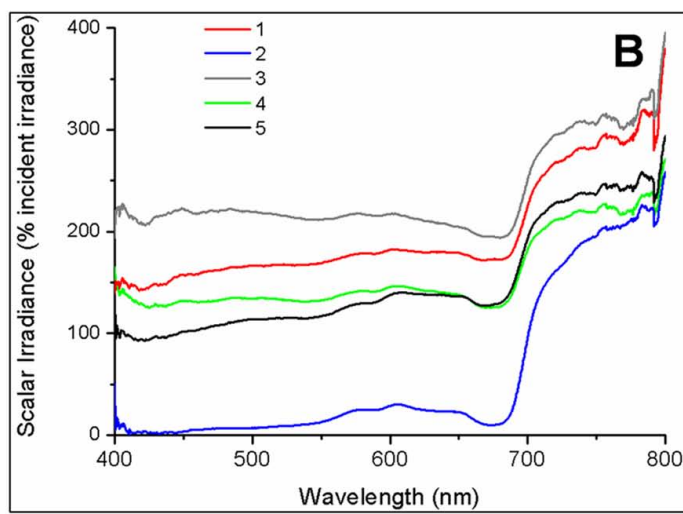

(indicated as arrow or sensor tip, 1-5). Black scale bar is $2 \mathrm{~mm}$. (B) Single scalar irradiance spectra $(400-800 \mathrm{~nm})$ at the measurement points (1-5). 


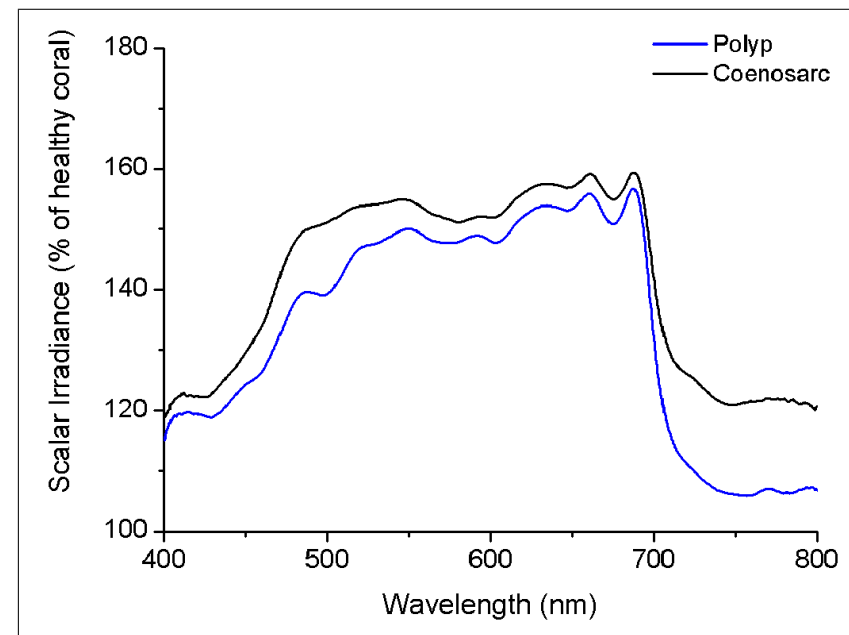

FIGURE 5 | Effect of bleaching on the tissue surface scalar irradiance of a coral. The figure shows spectral scalar irradiance for coenosarc (black) and polyp (blue) tissue of a bleached Goniastrea aspera, expressed as percentage of healthy coral.

scalar irradiance decreased from $\sim 176$ to $16 \%$ of the incident downwelling irradiance. In many cases, we noted a subsurface maximum 50-100 $\mu \mathrm{m}$ below the tissue surface, where no attenuation or even an increase in scalar irradiance occurred. This subsurface maximum was most pronounced at wavelengths around 550-650 nm (Figure 6A), i.e., outside major absorption peaks of photopigments. Most of the light was absorbed in the upper tissue layers and spectra close to the skeleton were more similar in intensity (Figures 6A,B). In the NIR region, no attenuation occurred within coenosarc tissue and high values of around 220$240 \%$ of incident downwelling irradiance remained (Figures 6A and 7A). In contrast, NIR did significantly attenuate from surface to skeleton inside polyp tissue from $~ 306$ to $124 \%$ of the incident downwelling irradiance (Figure 6B).

\section{OXYGEN MICROENVIRONMENT AND PHOTOSYNTHESIS WITHIN CORAL TISSUE}

Oxygen measurements within illuminated coral tissue revealed a steady increase in $\mathrm{O}_{2}$ concentration from the tissue surface toward the skeleton (Figure 7B). Maximum $\mathrm{O}_{2}$ concentrations at the tissue-skeleton interface reached $\sim 800 \mu \mathrm{M}(\sim 400 \%$ air saturation), which was about $240 \mu \mathrm{M}$ higher than the $\mathrm{O}_{2}$ concentration at the tissue surface. Gross photosynthesis increased with distance from the surface until $\sim 300 \mu \mathrm{m}$ within the tissue, where it peaked at $\sim 18.9( \pm 4.7 \mathrm{SE}) \mathrm{nmol} \mathrm{O}_{2} \mathrm{~cm}^{-3} \mathrm{~s}^{-1}$. The peak in gross photosynthesis correlated with a zone in the tissue exhibiting the highest scalar irradiance attenuation (compare Figures 7A,B). Photosynthesis was lowest at the coral tissue surface and at the tissue-skeleton interface $(8.3 \pm 2.5$ and $10.9 \pm 3.0 \mathrm{nmol} \mathrm{O}_{2} \mathrm{~cm}^{-3} \mathrm{~s}^{-1}$, respectively; Figure 7B).

The relationship between incident downwelling photon irradiance and the photon scalar irradiance for visible wavelengths (400-700 nm) was measured at the tissue-skeleton interface $\sim 1000 \mu \mathrm{m}$ within polyp tissue. There was a constant linear relationship between incident irradiance and the scalar irradiance level at the tissue-skeleton interface $\left(r^{2}>0.99\right.$; Figure 8). Over the range of experimental downwelling photon irradiances (150$2000 \mu$ mol photons $\mathrm{m}^{-2} \mathrm{~s}^{-1}$ ) only about $1 / 10$ was measured as photon scalar irradiance within this optical niche.

\section{DISCUSSION}

In this study, we used fiber-optic microprobes to obtain the first detailed measurements of vertical and lateral light gradients within and across coral tissues in several species. While the chemical
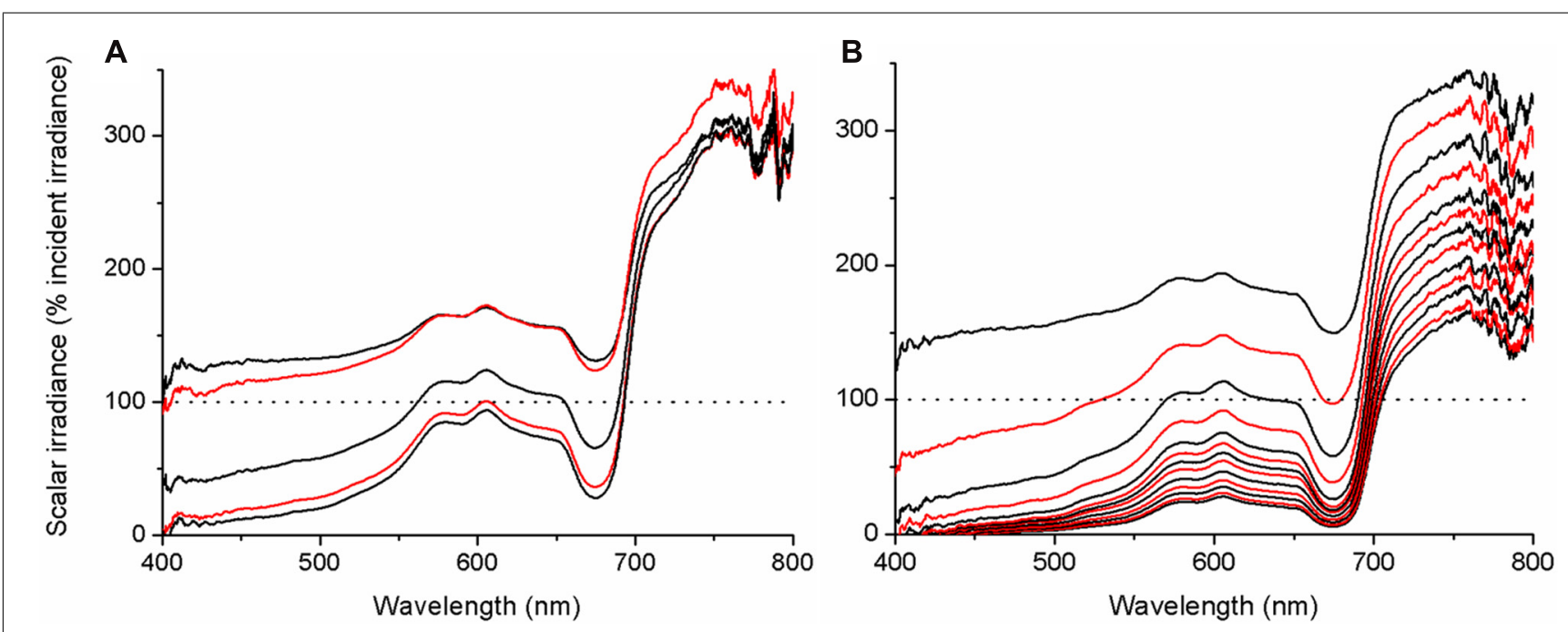

FIGURE 6 | Microprofiles of spectral scalar irradiance within coral tissue. Representative profiles measured in the coral Montastrea curta within (A) coenosarc (tissue thickness $\sim 400 \mu \mathrm{m}$ ) and (B) polyp tissue (tissue thickness $\sim 1200 \mu \mathrm{m}$ ). Scalar irradiance was normalized to the incident downwelling spectral irradiance, $E_{d}$; dotted line represents $100 \% E_{d}$. The uppermost

spectrum (black) represents measurements taken at the coral surface and subsequent spectra correspond to increments of $100 \mu \mathrm{m}$ with the lowermost spectrum equaling measurements over the coral skeleton. Spectra are colored in an alternating fashion (black-red) for clarity. 


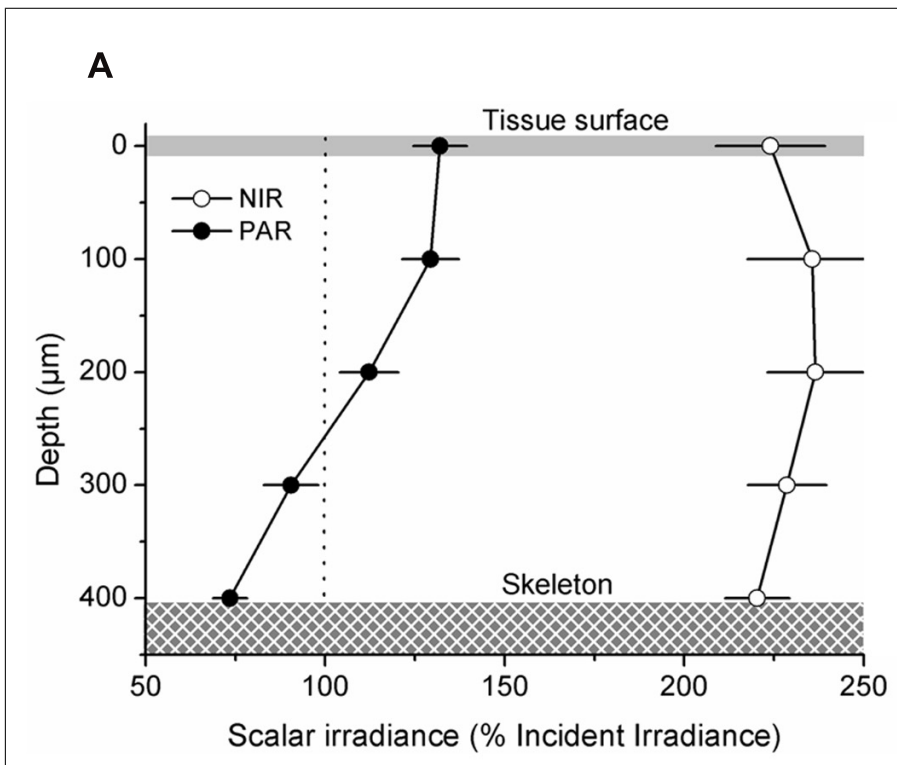

FIGURE 7 | Microgradients of light, $\mathbf{O}_{2}$, and photosynthesis within coral tissue. Microprofiles were measured within $\sim 400 \mu \mathrm{m}$ thick coenosarc tissues of the coral Montastrea curta from just above the skeleton (depth $400 \mu \mathrm{m}$ ) to the coral surface (depth $0 \mu \mathrm{m}$ ). Data points are mean values $( \pm \mathrm{SE} ; n=4)$ (A) Mean photosynthetically available radiation (PAR, 400-700 nm; closed symbols) and near-infrared radiation (NIR, 700-800 nm;

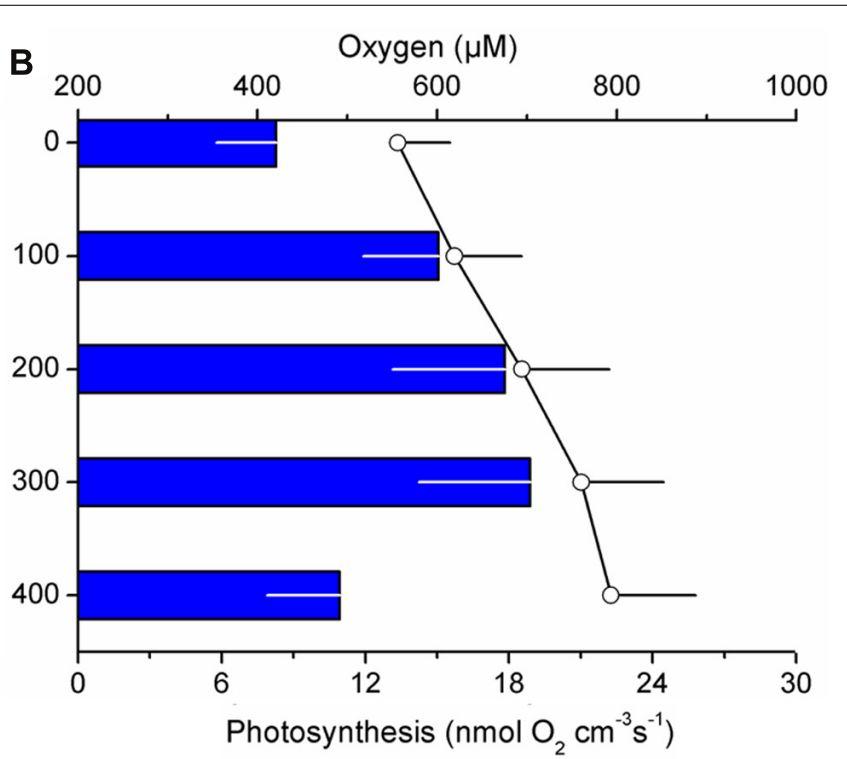

open symbols) scalar irradiance profiles. Scalar irradiance was normalized to the incident downwelling irradiance. (B) Average $\mathrm{O}_{2}$ concentration $(\mu \mathrm{M}$; open symbols) and gross photosynthesis ( $\mathrm{nmol} \mathrm{O}_{2} \mathrm{~cm}^{-3} \mathrm{~s}^{-1}$; blue bars). For clarity error bars of $\mathrm{O}_{2}$ concentration and photosynthesis are only + and -, respectively. The downwelling photon irradiance $E_{d}$ (PAR) was $640 \mu \mathrm{mol}$ photons $\mathrm{m}^{-2} \mathrm{~s}^{-1}$ microenvironment of corals has been explored in several studies since microsensors were introduced to coral research (Kühl et al., 1995), only a few examples of scalar irradiance measurements in corals have been published and these have been hampered by difficulties in entering and/or precise positioning in the tissue (Kühl et al., 1995; Kaniewska et al., 2011). Hitherto, tissue

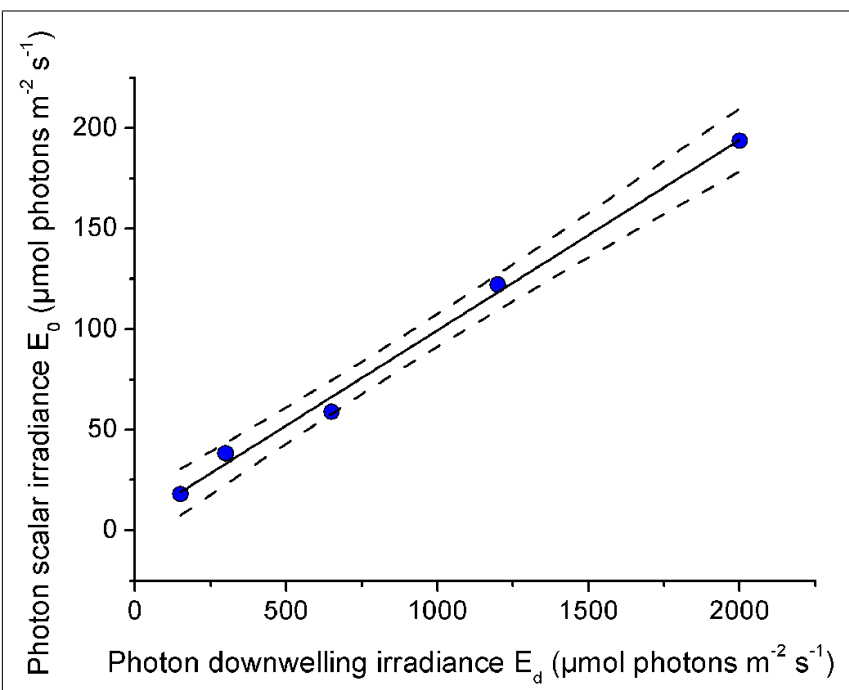

FIGURE 8 | Effect of incident photon irradiance on within tissue photon scalar irradiance $(\mathbf{4 0 0 - 7 0 0 ~} \mathbf{~ m m})$. The microsensor was positioned at a depth of $1000 \mu \mathrm{m}$ within the polyp tissue just above the skeleton of the coral Platygyra lamellina. Black line illustrates a linear fit $\left(r^{2}>0.99\right)$ and dashed lines represent $\pm 95 \%$ confidence intervals. effects on coral light fields have largely been ignored in coral optics studies that have mostly focused on the role of diffuse backscatter from the coral skeleton and from the coral tissue into the surrounding seawater (Enriquez et al., 2005; Teran et al., 2010). Combining micro-incision with scalar irradiance profiling, we have now unequivocally demonstrated the presence of light gradients in corals and present the first evidence that tissue optics is an important factor to consider in coral photobiology.

Direct in hospite micro-scale light measurements in corals differ from predictions in previous modeling studies, which have calculated that internal irradiance is homogenously enhanced compared to the external environment based on known downwelling irradiance regimes (Enriquez et al., 2005; Teran et al., 2010). We show that a clear spatial stratification exists within coral tissue, where scalar irradiance in the upper coral tissue layers $(0-100 \mu \mathrm{m})$ can reach up to $200 \%$ of incident downwelling irradiance, whilst lower cell layers are subject to more light-limiting conditions (Figures 6B and 8). Our results thus suggest that the light microhabitat of corals is not only determined by the properties of the skeleton, but also largely by the characteristics of the tissue.

Until now, coral tissue has simply been treated as a thin layer of light absorbing particles (i.e., zooxanthellae) on top of the lightdiffusing skeleton and overlain by seawater (Teran et al., 2010). We know from other systems, however, such as plant leafs or animal skin, that the properties of the tissue itself can significantly enhance light fields at the tissue interface due to scattering and internal reflection (Anderson and Parrish, 1981; Vogelmann et al., 1996; Spilling et al., 2010). The peak of scalar irradiance observed here in the upper cell layers suggests that substantial scattering 
and photon-trapping must occur at the tissue-water interface, potentially resulting from a mismatch in the refractive index of coral tissue and water (Kühl and Jørgensen, 1994). Nevertheless, our results also confirm that the earlier-reported diffuse scattering component of the skeleton is functional in hospite (Enriquez et al., 2005), as seen by a decrease in light attenuation toward the skeleton surface (Figure 6B). The occurrence and significance of skeleton backscatter is further exemplified by the continuous enhancement of NIR throughout the coenosarc tissue, where no pigments are present that absorb over these wavelengths (Figure 7A).

We hypothesized that with increasing incident irradiance, within-tissue PAR would increase exponentially as more light would be transmitted through the tissue and interact with the skeleton, thereby increasing the relative importance of backscattered light from the skeleton at the tissue-skeleton interface. However, we found a constant linear relationship between PAR at the tissue-skeleton interface and incident PAR (Figure 8). Photons are thus efficiently absorbed before they get scattered by the skeleton, indicating that the coral tissue itself also contributes to the high efficiency of light absorption found in corals (Stambler and Dubinsky, 2005). Scalar irradiance at the tissue surface increased by $150 \%$ in a bleached coral relative to the surface scalar irradiance in a healthy coral (Figure 5). This was less than expected according to coral skeleton scattering theory (Teran et al., 2010) and again suggests that other light redistributing mechanisms occur within the tissue. However, the nature of light gradients and thus the relative importance of tissue vs skeleton optics will be variable. Coral tissue varies in thickness, metabolite composition, symbiont and host pigment distribution, and abundance, all of which modulate coral tissue optics. Additionally, the role of skeleton optics is variable due to differences in morphology and density. For instance, thick corallite walls guide more light into the coral interior, whilst more dense structures facilitate diffuse backscattering (Highsmith, 1981). Therefore, the optical microenvironment within corals is the result of a complex interplay between skeleton and tissue optical properties, which clearly deserves further investigations.

Coral tissue surface scalar irradiance differed on a spatial scale between coral species and tissue types, despite identical incident irradiance regimes (Figures 3A,B). Since we excluded the potential for any interference with colony and/or macro-scale light-regulating factors such as colony morphology and orientation (Anthony etal., 2005), we conclude that the observed differences are caused by micro-scale optical properties of coral tissue and skeleton. In faviid corals, host pigments are often locally concentrated toward the polyp mouth (e.g., Salih etal., 2000; Oswald et al., 2007; but see spectral signatures in Figure 2). The enhanced tissue surface scalar irradiance of polyp over coenosarc tissue may be explained partly by the presence of such pigments, which effectively reflect, fluoresce, and scatter light (Schlichter et al., 1988; Salih et al., 2000).

Previous studies have shown the presence of tissue type-related spatial heterogeneity in photosynthesis (Ralph et al., 2002; Hill et al., 2004; Al-Horani et al., 2005). For instance, in the coral Galaxea fascicularis $\mathrm{O}_{2}$ production was shown to be about 10 times higher over polyp than over coenosarc tissue (Al-Horani et al., 2005). Such differences may likely be related to distinct light microenvironments in the coral tissue. For productivity comparisons between species under identical incident irradiance regimes it appears crucial to consider the ability of corals to modulate their own light regime by skeleton structure and tissue organization/movement (Figures 3A,B). Tissue and skeleton optical properties have a strong effect on the local light environment that may partly explain observed species- and tissue type-related differences in photosynthesis.

Our results show that Symbiodinium populations, inhabiting oral and aboral coral tissue layers of faviid corals, experience steep light gradients with scalar irradiance reaching down to $10 \%$ of the surface irradiance in deeper tissue layers (Figure 6B); the vertical attenuation of light observed in the coral tissue over a few hundred microns is comparable to the reduction in irradiance that occurs between surface waters and $>25 \mathrm{~m}$ depth in oceanic waters (Kirk, 1994). Our findings thus call for a revision of the current view on the optical environment surrounding zooxanthellae.

On the scale of a single colony, irradiance gradients between light exposed and shaded tissue can lead to both a distinct distribution of Symbiodinium clades and/or differential photoacclimation of the latter (Rowan et al., 1997; Toller et al., 2001; Ulstrup et al., 2006; Sampayo et al., 2007). The potential for such mechanisms occurring within tissue on a vertical micro-scale, for instance between oral and aboral tissue layers, is not known for corals, but is well-studied for terrestrial leaves (Schreiber et al., 1996). It is, e.g., known that shade-adapted chloroplasts exist in the lower tissue layers of sun-adapted leaves and chloroplasts deep within leaves are photoacclimated to local irradiance regimes (Terashima, 1989). We found that maximum rates of photosynthesis occurred in lower parts of coral tissue and not at the surface where scalar irradiance was at its maximum (Figure 7B). In fact, the spatial relationship between photosynthesis and light observed here is similar to results obtained from spinach leaves where photosynthetic $\mathrm{O}_{2}$ production showed a peak deep within the leaf, whilst irradiance maxima were obtained at the top part of the leaf (Nishio et al., 1993). These findings underscore the potential for photoacclimation to different light microclimates within coral tissue.

Clades and sub-clades of Symbiodinium exhibit a range of light-harvesting strategies (Reynolds et al., 2008; Ragni et al., 2010; Kraemer et al., 2012) and it will be interesting in the future to ascertain the location of various clades in coral species that harbor more than one clade, relative to the actual light field characteristics. The optical environment is a primary factor controlling the activity and distribution of phototrophic organisms and the presence of intratissue light gradients must have an effect on the ecophysiology of zooxanthellae in yet unknown ways.

Our results also have implications for the understanding of coral bleaching patterns. It has been observed that thick-tissued corals survive stress events better than thin-tissued ones (Loya et al., 2001). It has also been hypothesized that thick coral tissue could provide sheltered light environments for resident zooxanthellae, thereby increasing stress resilience and the survival of thick-tissued corals (Hoegh-Guldberg, 1999). We show here that thick-tissued corals do indeed harbor such sheltered optical microniches (Figures 6A,B). This photoprotection is substantial as even under conditions of stressful excess radiation (incident PAR irradiance levels of $\sim 2000 \mu \mathrm{mol}$ photons $\mathrm{m}^{-2} \mathrm{~s}^{-1}$ ) thick coral 
tissue can harbor low light niches for photosynthesis experiencing about $1 / 10$ of incident irradiance $\left(200 \mu \mathrm{mol}\right.$ photons $\mathrm{m}^{-2} \mathrm{~s}^{-1}$; Figure 8).

Yet another option is that habitat heterogeneity is favored in thick-tissued corals, which in turn leads to a larger symbiont pool with diverse phenotypic or genotypic characteristics and stress resilience (Rowan et al., 1997). We found habitat heterogeneity both in the optical and the chemical environment (Figures 7A,B). The coral skeleton represents a diffusion barrier for chemical species, which will lead to a relative build-up of gases in lower tissue layers toward the tissue-skeleton interface as shown here by an increasing $\mathrm{O}_{2}$ concentration up to $\sim 400 \%$ air saturation (Figure 7B). Thus, tissue thickness will favor microenvironmental heterogeneity. Whether this then favors a greater pool of symbiont populations (or subpopulations) and if this translates to increased stress resilience remains to be investigated.

In conclusion, we show here the first evidence for the presence of strong light gradients within the tissue of symbiotic corals. The optical properties of coral tissue have an important role in controlling microenvironmental light fields within corals. Our results imply that zooxanthellae within one single polyp can be subject to different light microenvironments with irradiance levels spanning over one order of magnitude. These results call for a revision of our current understanding of the interaction between light and corals and provide the very basis for future investigations on microenvironmental optical controls of coral photo- and stress physiology.

\section{MATERIALS AND METHODS CORAL SAMPLES}

Corals were collected from shallow waters ( $<3 \mathrm{~m}$ depths) on the reef flat of the Heron Island lagoon, Great Barrier Reef, Australia $\left(152^{\circ} 06^{\prime} \mathrm{E}, 20^{\circ} 29^{\prime} \mathrm{S}\right)$. We selected several species of faviid corals (Favites abdita, Goniastrea aspera, Montastrea curta, Platygyra lamellina) suitable for intratissue microsensor measurements (i.e., thick tissue and minimal mucus secretion; Alieva etal., 2008). We also sampled small coral fragments $(<5 \mathrm{~cm}$ diameter) of the branching Pocillopora damicornis (Pocilloporidae) and the foliaceous Pavona decussata (Agariciidae) because they have contrasting micro-scale properties (pigment composition and microtopography) compared to faviids. Samples were transported to the permanent coral holding facility at the University of Technology, Sydney, where corals were maintained under continuous flow at $25^{\circ} \mathrm{C}$, salinity of 33 and a photon irradiance of $200 \mu \mathrm{mol}$ photons $\mathrm{m}^{-2} \mathrm{~s}^{-1}(400-700 \mathrm{~nm} ; 12 / 12 \mathrm{~h}$ light-dark cycle).

\section{SCALAR IRRADIANCE MICROSENSOR MEASUREMENTS}

Experiments were conducted with coral fragments placed in a custom-made black acrylic flow chamber supplied with seawater (as above) at a flow velocity of $\sim 3 \mathrm{~cm} \mathrm{~s}^{-1}$. Samples were illuminated vertically from above with a collimated light beam from a fiber-optic tungsten-halogen lamp (KL-2500, Schott $\mathrm{GmbH}$, Germany), equipped with a heat filter and a collimating lens. The complete set-up was covered with black cloth to avoid stray light. Fiber-optic scalar irradiance microprobes with a spherical tip diameter of $80-100 \mu \mathrm{m}$ were used to map light microenvironments in the corals (Lassen et al., 1992). The microprobes were mounted on a PC-controlled motorized micromanipulator for automatic profiling (Pyro-Science GmbH, Germany), at an angle of $45^{\circ}$ relative to the vertically incident light (to avoid self-shading, see Lassen etal., 1992). The micromanipulator was fixed onto a heavy-duty vibration-free metal stand. Scalar irradiance spectra were recorded with the microprobes connected to a PC-controlled fiber-optic spectrometer controlled by the manufacturers software (USB2000+ and Spectrasuite, Ocean Optics, USA). Positioning of the microprobe was facilitated by the manufacturers software (Profix, Pyro-Science GmbH, Germany).

Scalar irradiance at the coral tissue surface was mapped at coenosarc (tissue connecting two polyps) and polyp tissue for the investigated coral species (Figure 1). These tissue types were chosen because of known differences in photobiology and pigment composition (e.g., Hill et al., 2004; Ulstrup et al., 2006). First, reference measurements of the incident downwelling irradiance $\left(E_{\mathrm{d}}\right)$ were done over a black non-reflective surface as described previously (e.g., Kühl and Jørgensen, 1992), followed by measurements at the coral surface. The coral surface was defined as the depth where the sphere of the sensor just touched the tissue. By rearranging the aquarium and/or the coral, but not the sensor or the incident light, we were able to measure coral surface irradiance at the identical spot in the incident light field, where $E_{\mathrm{d}}$ was measured, thereby avoiding potential artifacts due to heterogeneities in the incident light field. Differences in scalar irradiance were thus solely related to the optical properties of corals. Since we were interested in understanding how coral micro-scale properties and not gross morphology (i.e., growth form, etc.) modulate tissue light regimes, we only measured in locations that were directly exposed to the vertically incident collimated light beam. For each of the measured coral species, nine replicate measurements were done on randomly chosen coral polyps.

To investigate the impact of reduced pigmentation on coral tissue optics, we also measured a bleached and normally (darkbrownish) pigmented piece of Goniastrea aspera. The bleached coral originated from an experimental coral tank and was assessed to be severely bleached according to the color reference chart (score

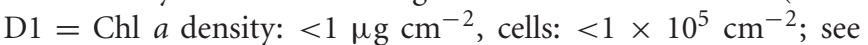
Siebeck et al., 2006). The tissue structure was visually assessed as healthy and uncompromised.

For measuring light gradients inside the coral tissue, a microincision had to be made in order to allow smooth tissue penetration by the sensor without indentation - a major problem in earlier attempts to measure light profiles in coral tissue. We found that a double-edged diamond knife $\left(60^{\circ}\right.$, blade thickness $200 \mu \mathrm{m}$, effective blade thickness $<100 \mu \mathrm{m}$; ProSciTech Pty Ltd, USA) was very suitable for such purpose. Diamond knifes are commonly used in tissue micro-surgery because they perform highly precise and minimally invasive cuts. Incisions were made carefully under a dissecting microscope with the knife inserting the animal tissue at diagonal angles until the skeleton was reached. After the incision, the coral tissue contracted somewhat and after $\sim 5-10$ min extrusion of mesenterial filaments, and tissue movement, often started coating sensor tips and interfering with the measurements. Therefore, measurement of each scalar irradiance profile commenced 
immediately after the incision was made and was finished within 1-3 min. For each profile, the microsensor was carefully inserted into the cut until the skeleton surface was reached, by means of the micromanipulator and the automatic profiling function of the motor (step sizes of $50-100 \mu \mathrm{m}$ ). The position of the skeleton surface within the tissue was easily identified as a minimal retraction/bending of the optical fiber. Subsequently, profiling was done upward from the skeleton surface into the overlying tissue in steps of $100 \mu \mathrm{m}$ logging the average of 10 spectra at each measuring depth until reaching the tissue surface (Figure 1).

To investigate the effect of changes in the ambient irradiance regime on the within tissue scalar irradiance we measured scalar irradiance within the polyp tissue ( $\sim 1000 \mu \mathrm{m}$ depth) of Platygyra lamellina under increasing levels of downwelling photon irradiance spanning the range from 0 to $2000 \mu \mathrm{mol}$ photons $\mathrm{m}^{-2} \mathrm{~s}^{-1}$.

Raw spectra were integrated between (400-700 nm, PAR) and (700-800 nm, NIR) using the mathematical integration function of Origin Pro 8.0 (Origin, USA). Spectral profiles were normalized to $E_{\mathrm{d}}$ and smoothed if noisy, using the Savitzky-Golay function of Origin with a 50 point window; visual inspection of spectra before and after smoothing showed no loss of spectral details.

\section{$\mathbf{0}_{2}$ MICROSENSOR MEASUREMENTS}

We used Clark-type $\mathrm{O}_{2}$ microelectrodes with a tip size of $25 \mu \mathrm{m}$, a $90 \%$ response time of $<0.5 \mathrm{~s}$ and a stirring sensitivity of $\sim 1 \%$ (Revsbech, 1989; OX25, Unisense AS, Denmark). Sensors were linearly calibrated against air saturated water and anoxic water (flushed with $\mathrm{N}_{2}$ ). The percent air saturation in the seawater at experimental temperature and salinity was transformed to $\mathrm{O}_{2}$ concentration ( $\mu \mathrm{mol} \mathrm{O} \mathrm{O}_{2}^{-1}$ ) as described previously (Garcia and Gordon, 1992). The $\mathrm{O}_{2}$ microsensor measurements inside the coral tissue were conducted using a similar approach as with the

\section{REFERENCES}

Al-Horani, F. A., Ferdelman, T., AlMoghrabi, S. M., and De Beer, D. (2005). Spatial distribution of calcification and photosynthesis in the scleractinian coral Galaxea fascicularis. Coral Reefs 24, 173-180.

Alieva, N. O., Konzen, K. A., Field, S. F., Meleshkevitch, E. A., Hunt, M. E., Beltran-Ramirez, V., Miller, D. J., Wiedenmann, J., Salih, A., and Matz, M. V. (2008). Diversity and evolution of coral fluorescent proteins. PLoS ONE 3, e2680. doi: 10.1371/journal.pone.0002680

Anderson, R. R., and Parrish, J. A. (1981). The optics of human skin. J. Invest. Dermatol. 77, 13-19.

Anthony, K. R. N., Hoogenboom, M. O., and Connolly, S. R. (2005). Adaptive variation in coral geometry and the optimization of internal colony light climates. Funct. Ecol. 19, 17-26.

Brown, B. E. (1997). Coral bleaching: causes and consequences. Coral Reefs 16, 129-138.

Enriquez, S., Mendez, E. R., and Iglesias-Prieto, R. (2005). Multiple scattering on coral skeletons enhances light absorption by symbiotic algae. Limnol. Oceanogr. 50, 1025-1032.

Falkowski, P. G., Jokiel, P. L., and Kinzie, R. A. (1990). "Irradiance and corals," in Ecosystems of the World, Vol. 25, Coral Reefs, ed. Z. Dubinsky (Amsterdam: Elsevier), 89-107.

Garcia, H. E., and Gordon, L. I. (1992). Oxygen solubility in seawater: better fitting equations. Limnol. Oceanogr. 37, 1307-1312.

Glynn, P. W. (1996). Coral reef bleaching: facts, hypotheses and implications. Glob. Change Biol. 2, 495-509.

Highsmith, R. C. (1981). Lime-boring algae in hermatypic coral skeletons. J. Exp. Mar. Biol. Ecol. 55, 267-281.

Hill, R., Schreiber, U., Gademann, R., Larkum, A. W. D., Kühl, M., and Ralph, P. J. (2004). Spatial heterogeneity of photosynthesis and the effect of temperature-induced bleaching conditions in three species of corals. Mar. Biol. 144, 633-640.

Hoegh-Guldberg, O. (1999). Climate change, coral bleaching and the future of the world's coral reefs. Mar. Freshw. Res. 50, 839-866.

fiber-optic microprobes (see above). However, the $\mathrm{O}_{2}$ microsensors approached the coral surface at an angle of $\sim 10^{\circ}$ relative to the vertical as this facilitated better tissue penetration. For each measuring depth, we estimated steady state $\mathrm{O}_{2}$ concentrations followed by gross photosynthesis estimates using the light-dark shift technique (see Revsbech and Jørgensen, 1983 for detailed description). Data were recorded with a conventional strip-chart recorder with a rapid time response (BD25, Kipp \& Zonen, The Netherlands).

\section{AUTHOR CONTRIBUTIONS}

Daniel Wangpraseurt and Michael Kühl designed research; Daniel Wangpraseurt performed research; Anthony W. D. Larkum, Peter J. Ralph, and Michael Kühl contributed new reagents/analytic tools; Daniel Wangpraseurt, Anthony W. D. Larkum, and Michael Kühl analyzed data; and Daniel Wangpraseurt, Anthony W. D. Larkum, and Michael Kühl wrote the paper.

\section{ACKNOWLEDGMENTS}

The research was conducted under research permits for field work on the Great Barrier Reef (research permit numbers: G11/34670.1 and G09/31733.1). We thank M. Lichtenberg and K. E. Brodersen for help with data collection and J. Franklin for insightful discussions. L. F. Rickelt is thanked for manufacturing scalar irradiance microprobes. We acknowledge the help of Dr D. Nielsen and the staff at Heron Island Research Station during field work. This research was funded by grants from the Australian Research Council (to Anthony W. D. Larkum and Peter J. Ralph), the Danish Council for Independent Research INatural Sciences (to Michael Kühl), the Plant Functional Biology and Climate Change Cluster (to Daniel Wangpraseurt, Michael Kühl, and Peter J. Ralph), and a postgraduate stipend from the University of Technology, Sydney (to Daniel Wangpraseurt).

Jones, R. J., Hoegh-Guldberg, O., Larkum, A. W. D., and Schreiber, U. (1998). Temperature-induced bleaching of corals begins with impairment of the $\mathrm{CO}_{2}$ fixation mechanism in zooxanthellae. Plant Cell Environ. 21, 1219-1230.

Kaniewska, P., Magnusson, S. H. Anthony, K. R. N., Reef, R. Kühl, M., and Hoegh-Guldberg, O. (2011). Importance of macro- versus microstructure in modulating light levels inside coral colonies. J. Phycol. 47, 846-860.

Kirk, J. (1994). Light and Photosynthesis in Aquatic Ecosystems. New York: Cambridge University Press.

Kraemer, W. E., Caamano-Ricken, I., Richter, C., and Bischof, K. (2012). Dynamic regulation of photoprotection determines thermal tolerance of two phylotypes of Symbiodinium clade $\mathrm{A}$ at two photon fluence rates. Photochem. Photobiol. 88, 398-413.

Kühl, M. (2005). Optical microsensors for analysis of microbial communities. Methods Enzymol. 397, 166-199. Kühl, M., Cohen, Y., Dalsgaard, T., Jørgensen, B. B., and Revsbech,
N. P. (1995). Microenvironment and photosynthesis of zooxanthellae in scleractinian corals studied with microsensors for $\mathrm{O}_{2}, \mathrm{pH}$ and light. Mar. Ecol. Prog. Ser. 117, 159-172.

Kühl, M., and Jørgensen, B. B. (1992). Spectral light measurements in microbenthic phototrophic communities with a fiber-optic microprobe coupled to a sensitive diode array detector. Limnol. Oceanogr. 37, 1813-1823.

Kühl, M., and Jørgensen, B. B. (1994). The light-field of microbenthic communities - radiance distribution and microscale optics of sandy coastal sediments. Limnol. Oceanogr. 39, 1368-1398.

Lassen, C., Ploug, H., and Jørgensen, B. B. (1992). A fibre-optic scalar irradiance microsensor: application for spectral light measurements in sediments. FEMS Microbiol. Ecol. 86, 247-254.

Lesser, M. P. (1996). Elevated temperatures and ultraviolet radiation cause oxidative stress and inhibit photosynthesis in symbiotic dinoflagellates. Limnol. Oceanogr. 41, 271-283. 
Loya, Y., Sakai, K., Yamazato, K., Nakano, Y., Sambali, H., and Van Woesik, R. (2001). Coral bleaching: the winners and the losers. Ecol. Lett. 4, 122-131.

Muscatine, L., Mccloskey, L. R., and Marian, R. E. (1981). Estimating the daily contribution of carbon from zooxanthellae to coral animal respiration. Limnol. Oceanogr. 26, 601-611.

Nishio, J. N., Sun, J. D., and Vogelmann, T. C. (1993). Carbon fixation gradients across spinach leaves do not follow internal light gradients. Plant Cell 5, 953-961.

Oswald, F., Schmitt, F., Leutenegger, A. Ivanchenko, S., D’Angelo, C., Salih, A., Maslakova, S., Bulina, M., Schirmbeck, R., Nienhaus, G. U., Matz, M. V., and Wiedenmann, J. (2007). Contributions of host and symbiont pigments to the coloration of reef corals. FEBS J. 274, 1102-1109.

Ragni, M., Airs, R. L., Hennige, S. J., Suggett, D. J., Warner, M. E., and Geider, R. J. (2010). PSII photoinhibition and photorepair in Symbiodinium (Pyrrhophyta) differs between thermally tolerant and sensitive phylotypes. Mar. Ecol. Prog. Ser. 406, 57-70.

Ralph, P. J., Gademann, R., Larkum, A. W. D., and Kühl, M. (2002). Spatial heterogeneity in active chlorophyll fluorescence and PSII activity of coral tissues. Mar. Biol. 141, 639-646.

Revsbech, N. P. (1989). An oxygen microsensor with a guard cathode. Limnol. Oceanogr. 34, 474-478.

Revsbech, N. P., and Jørgensen, B. B. (1983). Photosynthesis of benthic microflora measured with high spatial-resolution by the oxygen microprofile method - capabilities and limitations of the method. Limnol. Oceanogr. 28, 749-756.

Reynolds, J. M., Bruns, B. U., Fitt, W. K., and Schmidt, G. W. (2008). Enhanced photoprotection pathways in symbiotic dinoflagellates of shallow-water corals and other cnidarians. Proc. Natl. Acad. Sci. U.S.A. 105, 13674 13678.

Rowan, R., Knowlton, N., Baker, A., and Jara, J. (1997). Landscape ecology of algal symbionts creates variation in episodes of coral bleaching. Nature 388, 265-269.

Salih, A., Larkum, A. W. D., Cox, G., Kühl, M., and Hoegh-Guldberg, O. (2000). Fluorescent pigments in corals are photoprotective. Nature 408, 850-853.

Sampayo, E. M., Franceschinis, L., Hoegh-Guldberg, O., and Dove, S. (2007). Niche partitioning of closely related symbiotic dinoflagellates. Mol. Ecol. 16, 3721-3733.

Schlichter, D., Fricke, H. W., and Weber, W. (1988). Evidence for PARenhancement by reflection, scattering and fluorescence in the symbiotic deep-water coral Leptoseris Fragilis (photosynthetically active radiation). Endocytobiosis Cell Res. 5, 83-94.

Schreiber, U., Kühl, M., Klimant, I., and Reising, H. (1996). Measurement of chlorophyll fluorescence within leaves using a modified PAM Fluorometer with a fiber-optic microprobe. Photosynth. Res. 47, 103-109.

Siebeck, U. E., Marshall, N. J., Kluter, A., and Hoegh-Guldberg, O. (2006). Monitoring coral bleaching using a colour reference card. Coral Reefs 25 , 453-460.

Spilling, K., Titelman, J., Greve, T. M., and Kühl, M. (2010). Microsensor measurements of the external and internal microenvironment of Fucus vesiculosus (Phaeophyceae). J. Phycol 46, 1350-1355.

Stambler, N., and Dubinsky, Z. (2005). Corals as light collectors: an integrating sphere approach. Coral Reefs 24, 1-9.

Teran, E., Mendez, E. R., Enriquez, S. and Iglesias-Prieto, R. (2010). Multiple light scattering and absorption in reef-building corals. Appl. Opt. 49, 5032-5042.

Terashima, I. (1989). Productive Structure of a Leaf. New York: Alan R. Liss.

Toller, W. W., Rowan, R., and Knowlton, N. (2001). Zooxanthellae of the Montastraea annularis species complex: patterns of distribution of four taxa of Symbiodinium on differen reefs and across depths. Biol. Bull. 201, 348-359.

Ulstrup, K. E., Ralph, P. J., Larkum, A. W. D., and Kühl, M. (2006). Intracolonial variability in light acclimation of zooxanthellae in coral tissues of Pocillopora damicornis. Mar. Biol. 149, 1325-1335.

Vogelmann, T. C. (1993). Plant tissue optics. Annu. Rev. Plant Physiol. 44, 231-251.

Vogelmann, T. C., and Björn, L. O. (1984). Measurement of light gradients and spectral regime in plant tissue with a fiber optic probe. Physiol. Plant. 60, 361-368.

Vogelmann, T. C., Martin, G., Chen, G. Y., and Buttry, D. (1991). Fiber optic microprobes and measurement of the light microenvironment within plant tissues. Adv. Bot. Res. 18, 255-295.

Vogelmann, T. C., Nishio, J. N., and Smith, W. K. (1996). Leaves and light capture: light propagation and gradients of carbon fixation within leaves. Trends Plant Sci. 1, 65-70.

Warner, M. E., Fitt, W. K., and Schmidt, G. W. (1999). Damage to photosystem II in symbiotic dinoflagellates: a determinant of coral bleaching. Proc. Natl. Acad. Sci. U.S.A. 96, 8007-8012.

Wilson, B. C., and Jacques, S. L. (1990). Optical reflectance and transmittance of tissues: principles and applications. IEEE J. Quantum Electron. 26, 2186-2199.

Conflict of Interest Statement: The authors declare that the research was conducted in the absence of any commercial or financial relationships that could be construed as a potential conflict of interest.

Received: 20 July 2012; paper pending published: 09 August 2012; accepted: 13 August 2012; published online: 27 August 2012.

Citation: Wangpraseurt D, Larkum AWD, Ralph PJ and Kühl M (2012) Light gradients and optical microniches in coral tissues. Front. Microbio. 3:316. doi: 10.3389/fmicb.2012.00316

This article was submitted to Frontiers in Aquatic Microbiology, a specialty of Frontiers in Microbiology.

Copyright (c) 2012 Wangpraseurt, Larkum, Ralph and Kühl. This is an open-access article distributed under the terms of the Creative Commons Attribution License, which permits use, distribution and reproduction in other forums, provided the original authors and source are credited and subject to any copyright notices concerning any third-party graphics etc. 